\title{
Transsphenoidal encephalocele masquerading as nasal mass in a 2-year-old boy
}

\author{
Suresh Chandran, ${ }^{1}$ Shilpee Raturi, ${ }^{1}$ Haroon M Pillay, ${ }^{2}$ Teo Eu-leong Harvey James ${ }^{3}$
}

'Department of Neonatology, KK Women's and Children's Hospital, Singapore

${ }^{2}$ Department of Neurosurgery, RIPAS Hospital, Bandar Seri Begawan, Brunei Darussalam ${ }^{3}$ Department of Diagnostic and Interventional Imaging, KK Women's and Children's Hospital, Singapore

\section{Correspondence to} Dr Suresh Chandran, schandran1312@yahoo.co.uk, nehasuresh.chandran@gmail. com

Accepted 19 February 2014

\section{CrossMark}

To cite: Chandran $S$, Raturi S, Pillay HM, et al. BMJ Case Rep Published online: [please include Day Month Year] doi:10.1136/ bcr-2013-201426

\section{DESCRIPTION}

A full-term male baby was born to nonconsanguineous parents. At birth his growth parameters were appropriate for age. On examination he had hypertelorism, broad nasal root and a cleft lip. Cranial ultrasound at birth was grossly normal except for partial agenesis of the corpus callosum. The cleft lip was repaired at 6 months of age. As part of the preoperative check, MRI of the brain was carried out. However it remained unreported. At 2 years of age (figure 1) he presented with recurrent nasal block and sleep disturbances. A detailed rhinoscopic examination showed a glistening mass in the right posterior nasal cavity and choana, causing a near total airway obstruction. Systemic examination was unremarkable. He had a normal ophthalmological evaluation. MRI carried out at 6 months was reviewed and showed a transsphenoidal encephalocele (TSE) with partial agenesis of the corpus callosum (figure 2). Neurosurgical opinion was sought and the consensus was to postpone surgery till second decade of life in

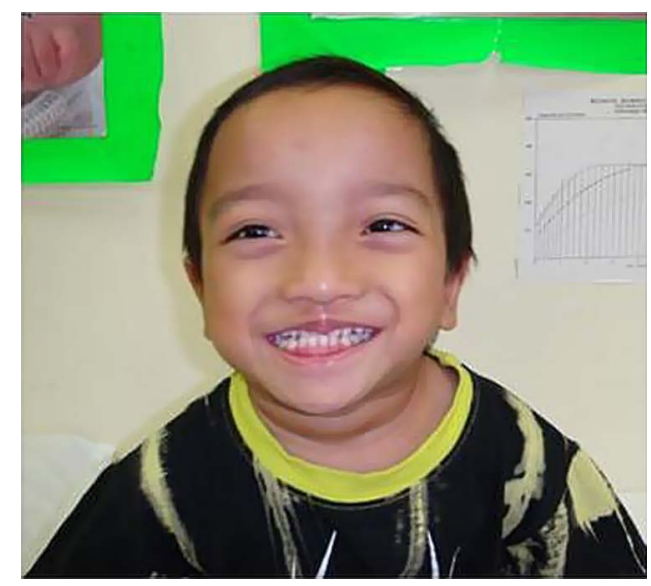

Figure1 Facial dysmorphism showing hypertelorism, broad nasal root and a cleft lip (repaired). view of the high-risk of hypothalamo-pituitary dysfunction following repair of the encephalocele.

Basal encephalocele (BE) occurs due to herniation of neural elements including pituitary gland or optic apparatus, through a defect in the skull base. TSE represents less than $5 \%$ of all $\mathrm{BE}$ with an estimated incidence of 1 in 700000 live-births. ${ }^{1}$ Clinical presentation is most often insidious except in those cases where a large herniation protrudes through the epipharynx. They are often associated with hypertelorism, broad nasal root, cleft lip/palate, optic nerve anomalies and agenesis of the corpus callosum. ${ }^{2}$ Non-contrast CT scan of the head can delineate the bony defects. MRI with contrast enhancement is useful in identifying any neural or vascular elements in the herniated encephalocele.

\section{Learning points}

- The presence of midline craniofacial anomalies in association with symptoms of nasal obstruction, persistent rhinorrhoea, visual deficits and/or endocrine dysfunction should alert physicians to the possible presence of basal encephalocele.

- If conservative management is planned a notification to his school teacher to keep him away from contact sports and to physicians treating him to avoid nasal suctioning is recommended.

- Indication for surgical intervention includes significant obstruction of respiratory pathway, repeated meningitis, rhinorrhoea and progressive visual defect attributable to the lesion. Endoscopic route is preferred because of the high rate of postoperative hypothalamo-pituitary dysfunction following transcranial approach. ${ }^{1}$ 
Acknowledgements The authors would like to express their gratitude to Dato Dr N Ravindranathan, Senior Consultant OMF Surgeon, RIPAS Hospital, Brunei, Darussalam for referring this case to them.

Contributors All authors contributed to the preparation, editing and finalisation of the manuscript and figures.

Competing interests None.

Patient consent Obtained.

Provenance and peer review Not commissioned; externally peer reviewed.

\section{REFERENCES}

1 Sanjari R, Mortazavi SA, Amiriv RS, et al. Intrasphenoidal meningoencephalocele: report of 2 rare cases and review of literature. Surg Neurol Int 2013; 4:5.

2 Caprioli J, Lesser RL. Basal encephalocele and morning glory syndrome. $\mathrm{Br} J$ Ophthalmol 1983;67:349-51.

3 Faggin R, Pentimalli L, Grazzini M, et al. Combined endoscopic-microsurgical approach for transsphenoidal (sphenopalatine) encephalocele with an intralesional pituitary gland. Case report. I Neurosurg Pediatr 2009; 4:262-5.

Copyright 2014 BMJ Publishing Group. All rights reserved. For permission to reuse any of this content visit http://group.bmj.com/group/rights-licensing/permissions.

BMJ Case Report Fellows may re-use this article for personal use and teaching without any further permission.

Become a Fellow of BMJ Case Reports today and you can:

- Submit as many cases as you like

- Enjoy fast sympathetic peer review and rapid publication of accepted articles

- Access all the published articles

- Re-use any of the published material for personal use and teaching without further permission

For information on Institutional Fellowships contact consortiasales@bmjgroup.com

Visit casereports.bmj.com for more articles like this and to become a Fellow 